\title{
Competence Oriented Education System
}

\author{
Veselin Vukotic $^{1}$, Maja Drakic-Grgur ${ }^{2}$ \\ ${ }^{1}$ Rector and Full professor of the University of Donja Gorica (UDG), Montenegro; Insti- \\ tute for Strategic Studies and Prognoses, Podgorica, Montenegro; Institute of Social Sci- \\ ences, Belgrade, Serbia (vukotic@t-com.me); \\ ${ }^{2}$ Associate professor of the University of Donja Gorica (UDG), Montenegro; Institute for \\ Strategic Studies and Prognoses, Podgorica, Montenegro (maja.drakic@udg.edu.me).
}

\begin{abstract}
We live in the time when collective entities of all kind are being crashed, when they go through invisible substantial transformation. The dominant social paradigm is moving focus from collective to an individual. This paper analyses the influence of changing social paradigm on education system. Why education system in new era has to be designed to provoke student's mind and make his/her spirit active, competent and critical in the complex world? Will such education model suppress current model within which students sit in their classrooms, absorb and memorize facts, and then just reproduce what have been served to them?
\end{abstract}

Keywords: Education, Energy, Idea, Individual Competence, Knowledge, Skills.

\section{Background of the Idea}

We live in the time when collective entities of all kind are being crashed, when they go through invisible substantial transformation. The dominant social paradigm is changing - the focus is being put to an individual. Instead of material wealth, physical goods, and property importance is given to the quality of living, experiences, enjoyment, pleasure, and highly estimated leisure. Jeremy Rifkin claims that intellectual capital was the driving force of the new era... According to him, concepts, ideas and images, not things, are real items of value in new era.
Wealth is not in material, physical capital any more, but in human imagination and creativity. [1] This means that human capital is the most important asset of a company. This transition to new paradigm is not just a mechanical change, but comprehensive, long and demanding process of social change, which requires development of individualistic culture and new way of thinking. This change requires significant changes of education system. Problems of education system are more visible in transition countries where collectivistic spirit from socialism is still very strong, however education system in all countries worldwide are facing the same challenges. This paper is looking for answers about the influence of the change of the dominant social paradigm on education system.

Current education system is based on passive knowledge, memorizing facts, "warehousing" information, the importance of formal achievements (diploma is important by itself) and strong division between theoretical knowledge and practical problems. This model can be described with the equation $S=P+V$, where $S$ is knowledge understood as the goal of education, $\mathrm{P}$ - theoretical lecturing and $V$ - practical lessons.

The new information era requires education system which will develops skills and competences, change student's way of thinking, and improve innovative and creative capacity of a student. This means 
that the transformation of current education system should be oriented to the development of critical thinking and empirical imagination, which is completely opposite from current model of our universities which are based on one single topic, one single subject, not on paradigm of free skills. [2]

Current education system is focused on profession, well-behaving, neat and starchy citizen, which is a part of social collectivity - it is education for the state. Should it be abandoned in new era? What reforms of education system are needed in order to efficiently overcome changes induced by the change of dominant social paradigm? Are there any directions we should follow in order to foresee future developments in this area? What are directions for future development of education system? How can education system become focused to an individual, its personality and character? How can it educate people to be creative and to accept challenges of real life game? Is there any "formula" which can explain all of this and enable transfer from one to another education model?

Why education is not passive adoption of facts and cultural traditions? Why education system has to be designed to provoke student's mind and make his/her spirit active, competent and critical in the complex world? Will such education model suppress current model within which students sit in their classrooms, absorb and memorize facts, and then just reproduce what have been served to them?

We touch upon all these issues in this paper trying to present the new model of education which we use at private University Donja Gorica (UDG) in Montenegro. [3]

\section{The Need for New Education Model}

Today's world is the world of permanent changes, global world of risk and uncertainty, not static world, where everything is determined and certain. Contemporary life in global world can be understood as the "ride" on the top of the (global) wave. When an individual tries to stop the wave, (s)he will get into the fight lost in advance. But when the one realizes the direction in which the wave is moving and understand invisible streams that move the wave, then (s)he can learn how to "surf".

There we come to the question if the knowledge was the goal of education in contemporary era. This question is heretically provocative, especially in time when the dominant opinion is that future developments depend on how much the society is knowledge-based. The thought that only knowledge-based society has the future is dominant today.[4] New education model which we discuss don't deny the importance of knowledge. However, we insist on analysis of knowledge and its importance from individual perspective. Knowledge is important depending on the context and influence it has on personal character, way of thinking, creativity, and entrepreneurial spirit of an individual...

A student in the new education model is not the person who passively absorbs formulas, definitions, factors, models, etc (elements of knowledge). New education model developed at UDG puts emphasis on the knowledge which can be transformed into individual ability and competence, into capacity of an individual to solve problems and be creative.

New education model rely on the assumption that knowledge is individual and Hayek's thesis that it is spread in 
head of individuals. There is no such thing as the collective knowledge.[5] This is emphasizing the role of individual in education system, i.e. the need of education system to focus on an individual.

From the perspective of an individual and individual competence we can understand knowledge as something we take from other people - not as something that comes out of us. We adopted our knowledge about relativity theory from Einstein, Pythagoras theorem is taken from Pythagoras, knowledge about class struggle from Marx, etc.

This raises logical question: how someone else's knowledge is converted in each individual? Can we achieve it simply, by inserting knowledge in the head of an individual, or there are some factors of conversion? These questions probably seems odd to a reader, maybe even senseless. This usually seems simple and clear to everybody, but the real issue lies in the fact that two persons who had learned (absorbed, memorized) exactly the same "amount" of knowledge achieved different results in solving problems in real life. Why? Is there some relation between the level of knowledge and the results of its implementation? Does the secret of education lie in this factor "well known to everybody"?

Can Einstein help us in looking for an answer to these question with his famous equation $\boldsymbol{E}=\boldsymbol{m} \cdot \boldsymbol{c}^{2}$ (hereafter EE) which shows that energy is the product of mass and squared speed of light? [6] This equation raise the question how mass is transformed into energy? When we speak about education, the question is how knowledge (mass) is transformed into ability and competence (energy)?

According to Einstein's solution, presented in simplified form, speed of life is the factor of convergence - factor of transformation. In other words, mass and energy can be transformed one to another. Factor of conversion in currency exchange is the exchange rate, while the speed of light is the factor of conversion when transforming the mass into energy.

\section{Elements of Education $\operatorname{Model} S=z \cdot i^{2}$}

When we speak about education, what is the "exchange rate" between knowledge and individual ability and competence? In the new education model we develop at UDG, we understand the goal of higher education as the development of individual capacity and competence. The factor of converting knowledge into individual competence is the squared level of the intensity of life of an individual. Written in the form of equation:

$$
S=z \cdot i^{2}
$$

- $\boldsymbol{S}$ - individual capacity and competence (immanent to energy in $\mathrm{EE}$ );

- $\boldsymbol{Z}$ - knowledge (immanent to mass in $\mathrm{EE})$;

- $\boldsymbol{i}$ - intensity of life (immanent to speed in $\mathrm{EE}$ ).

As already said, the goal of higher education in competence oriented education approach is the competence which an individual is acquiring during university education. It is the ability of an individual. Knowledge is not the goal itself - it is just one of the elements of individual ability and competence. The ability of an individual in the model is seen as the capacity to solve problems and find solutions in permanently changing circumstances. Individual capacity and competence always results in new achievements, new ideas, creativity and dynamics. The ability of an individual is initiating mental processes, which increase capacity for abstract thinking, imagination and new ideas. It is the background of Einstein thought: "Im- 
agination is more important than knowledge!"[8]

This understanding of ability of an individual as the goal of education (not education for specific profession), emphasize the need for education system which will "produce" (as an outcome) intellectual i.e. creative entrepreneurs. This means that each individual, no matter what he or she does, should be entrepreneurial and creative. This is particularly important in global environment where the average time spent on one job is 5 years. Quick changes and moving from one job to another, rapid technology changes and globalization require the ability of an individual, not concrete knowledge for specific job... As famous Montenegrin poet Njegos said: "Whatever comes, we are ready!"[9] This sentence is pointing out the importance of individual capacity to accept and overcome life challenges.

In a nutshell, the main product of new education model we implement at UDG will be graduated student who is the expert for uncertainty. Graduated student should be able to make decisions based on imperfect information, in permanently changing circumstances of global scene.

As knowledge is understood as something "taken from other people" it is crucial how it can be converted into capacity and competence of an individual. In other words, how can you convert components of education programs and curricula, information from text books and other literature into ability and competence of an individual? New education model which we develop at UDG see the intensity (speed) of life as the factor of conversion.

What is the intensity of life? It can be understood as the devotion to life; enjoying life and thinking about life! When you see human life as the gift from God, you can extend it only through creation. What an individual creates in life - it is the measure of his or her individual ability and competence.

Intensity of life consists of various activities and functions that each individual is conducting in a time unit. What is the level of someone's life intensity, if (s)he sleeps 12 hours a day? What is the level of the life intensity of an individual who have never traveled out of birth town? How intensive is the life of a person who communicates only with his close family and friends? What is the level of life intensity of a person who doesn't accept different life challenges, such as enjoyment or creative activities?

Intensity of life results in certain level of experience, but it doesn't have to be the case always. Experience is something that an individual has deeply passed through, something that has deeply engraved in his mind. Experience becomes integral part of mental constitution of a person. It is not just collection of memories - it is emotional and spiritual driver, which brings new impulses and new ideas.

Is there something more personal than the experience? Is the experience, acquired through understanding of life, some kind of human spiritual DNA which shapes a person's ideas? Einstein said that all true learning was experience and everything else was just information". [10]

Through intensity of life, each person is acquiring skills and competences.

Skills should be understood as the "domestication" of somebody else's knowledge acquired through education process. This "domestication" is achieved through development of personal affinities and vocation. Only knowledge which is transformed into skills is efficient. 
Competence is also the result of the intensity of life of an individual. Competence is the capacity of an individual to use his/her personal resources, to posses some self-driving impulses, be selfconfident and brave... Competence is understood as awaken intellect, moved by emotional, intuitive and creative forces within an individual!

If the role of intensity of life is so important in creating individual competence and ability, why dominant education system still focuses on memorizing and mechanical acquisition of knowledge?

If we get back to the Professor's equation which represent new education model $\boldsymbol{S}=\boldsymbol{z} \cdot \boldsymbol{i}^{2}$, then we can conclude what happens if $\boldsymbol{i}=\boldsymbol{0}$. In other words, what happens when an individual have lifeless knowledge.[11] Such knowledge will not produce competence and abilities of an individual. Does it mean that there are situations when we don't need knowledge $(z=0)$ ? Of course, the answer is no. From methodological point of view it is important to emphasize - acquisition of knowledge is a necessary, but not a sufficient condition for efficient education model.

\section{Concluding Remarks}

The essence of transforming current education system, which is evidently becoming inefficient in new global environment, lies in the relation between knowledge on one, and competence of an individual student on other side. It means that approach to education should move from current model expressed through $S=P+V$, where $S$ (goal of education) is knowledge, to the model expressed through equation $S=z \cdot i^{2}$, where $S$ (goal of education) is understood as individual competence and ability.[12]
Thus the focus of education moves from mechanical sum of theoretical lectures and practical lessons to the multiplier of knowledge and experience broadly defined as intensity of life. Current model (sum) is the result of mechanical approach to education system, while the new model (multiplier) is based on holistic, organic approach.

The goal of new education system is not knowledge itself. Knowledge should be acquired in order to develop someone's competence and individual abilities. This education model abandons the thesis that the amount of knowledge (collected information) in the head of student's increases student individual competence and creativity. Speaking from the perspective of the education equation presented in the paper, current education model put emphasis on variable $z$. However in contemporary global era the focus is moving in the direction of $\boldsymbol{i}$. In other words, it is necessary to adjust and harmonize activities from area of $z$ and $i$, in educational practice in systematic and holistic way.

\section{Annex:}

How can the knowledge be converted into individual competence and ability?

\section{Professor's Equation as Vector Model}

$$
[S]=[z] \times[i]^{2}
$$

Individual competence of the student - Elements of matrix $[S]$ in UDG practice:

$\left[\begin{array}{ll}\text { - solving problem } & \text { - energy } \\ \text { - recognize the opportunity } & \text { - creation } \\ \text { - compassionate (with } & \text { - sense of future } \\ \text { others) } & \text { - character } \\ \text { - action } & \text { - personality } \\ \text { - selfconfidence } & \text { - intellect } \\ \text { - noble spirit } & \text { - risk } \\ \text { - ideas } & \text { - critical thinking } \\ \text { - vision } & \text { - culture } \\ \text { - ambition } & \text { - competition spirit } \\ \text { - need } & \text { - recognize opportunities, } \\ \text { - life as a game } & \text { not struggle for positions }\end{array}\right.$


Knowledge of the student - Elements of matrix $[z]$ in UDG practice

\begin{tabular}{|c|c|}
\hline $\begin{array}{l}\text { - associative (not only } \\
\text { reproductive) leaming } \\
\text { - emotions (scribing } \\
\text { knowledge) } \\
\text { - notebook as the method } \\
\text { of binding knowledge } \\
\text { - professors (Montenegro, } \\
\text { region, world) - their } \\
\text { knowledge and character } \\
\text { - experts from the practice } \\
\text { - textbooks from famous } \\
\text { universities and written } \\
\text { by well known authors } \\
\text { - foreign and domestic } \\
\text { scientific journals } \\
\text { - network of international } \\
\text { experts } \\
\text { - interdisciplinary } \\
\text { - interactive } \\
\text { - classes in English } \\
\text { - professionalism } \\
\text { - attending classes } \\
\text { requirement }\end{array}$ & $\begin{array}{l}\text { - practical aspect of } \\
\text { classes (related to real } \\
\text { life) } \\
\text { - gradual displace of } \\
\text { textbooks with } \\
\text { collections of original } \\
\text { papers written by well } \\
\text { known authors (so } \\
\text { called hrestomatia) } \\
\text { - building the network of } \\
\text { knowledge from } \\
\text { different areas } \\
\text { - importance to develop } \\
\text { students' affinity to ask } \\
\text { questions and looking } \\
\text { for the answers on their } \\
\text { own } \\
\text { - importance of students' } \\
\text { orientation to (re)search } \\
\text { and look what they } \\
\text { (don't) know } \\
\text { - importance of Socrates } \\
\text { "I know that I know } \\
\text { nothing" }\end{array}$ \\
\hline
\end{tabular}

Intensity of Life of the student - Elements of matrix $[i]$ in UDG practice

\begin{tabular}{|c|c|}
\hline $\begin{array}{l}\text { - positive academic } \\
\text { environment } \\
\text { - will to succeed } \\
\text { - devotion to studies } \\
\text { - working conditions, } \\
\text { organization and } \\
\text { technology level } \\
\text { - activities at UDG } \\
\text { (public debates, } \\
\text { tribunes, exhibitions, } \\
\text { literary events, concerts, } \\
\text { etc. } \\
\text { - sport activities } \\
\text { - students' presentations } \\
\text { - the project "Ideas and } \\
\text { Character" - } \\
\text { implementing principles } \\
\text { of self-education and } \\
\text { self-creation } \\
\text { - entrepreneurship and } \\
\text { promoting } \\
\text { entrepreneurial abilities } \\
\text { - business and creative } \\
\text { entrepreneurship } \\
\text { - dress code and business } \\
\text { code } \\
\text { - communication culture } \\
\text { - general education (nice } \\
\text { literature and poetry) } \\
\text { - fine arts } \\
\text { - foreign languages (4-6) } \\
\text { - international } \\
\text { studies } \\
\text { sumooperation } \\
\text { Cetinje) }\end{array}$ & 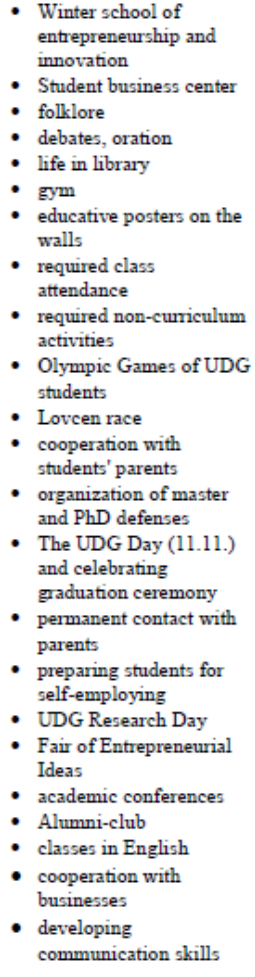 \\
\hline
\end{tabular}

\section{References:}

[1] J. Rifkin, "The age of access: The new culture of hypercapitalism, where all of life is a paid-for experience", New York: J.P. Tarcher/Putnam, 2000;

[2] See more: V. Vukotic, , $S=z \cdot i^{2}$ ", Proc. Of the Conference "Education and Development", Center for Economic Research, Institute of Social Sciences, Belgrade, pp.9-21, 2013;

[3] http://www.udg.edu.me/;

[4] OECD, "The Knowledge Based Economy", 1996, http://www.oecd. org/science/sci-tech/1913021.pdf;

[5] More on this: F. A. v. Hayek "The Use of Knowledge in Society," American Economic Review, Vol. 35, No. 4, Sep., 1945

[6] See interesting explanation in: B.Kox and J.Forshaw, "Why $E=m \cdot c^{2}$ ?", Dacapo Press, London, 2009;

[7] This equation is known as "Professor's Equation" named by Professor Veselin Vukotic, who is the author of this concept and the idea of this new education model;

[8] This sentence had initially been quoted in interview with A. Einstein by G.S. Viereck, The Saturday Evening Post, p.17, Oct. 26, 1929.

[9] P.P.Njegos, "The Mountain Wreath", Transl. by V. D. Mihailovic, Serbian Europe Publishing, Belgrade, 1997, line \#2496

[10] For Einstein's quotes see: A. Calaprice (ed), F.Dyson (foreword), A. Einstein (author), "The Ultimate Quotable Einstein", Princeton University Press, 2010;

[11] Following Einstein's equation $\boldsymbol{E}=\boldsymbol{m} \cdot \boldsymbol{c}^{\mathbf{2}}$, it is immanent to the question: "What is the level of energy of the parked car?"

[12] Example of an attempt to implement concept $\boldsymbol{S}=\boldsymbol{z} \cdot \boldsymbol{i}^{2}$ at University UDG, Montenegro is given in annex. 